\title{
Radiotherapy and Chemotherapy in Low-Grade Glioma (LGG)
}

\section{Behzad Saberi*}

Medical Research, Iran

Submission: May 21, 2019; Published: July 17, 2019

${ }^{*}$ Correspondence Author: Behzad Saberi, Medical Research, Iran

\section{Mini Review}

Although optimal timing is unclear, but radiotherapy is an important component of therapy for LGG. Early and delayed radiotherapy can be used for LGG depending on some factors like tumor associated symptoms and presence of risk factors determining the outcome. Poor prognostic factors can be incomplete resection, MIB-1 index elevation, astrocytic histology, more than 40 year of age, absence of $1 \mathrm{p} / 19 \mathrm{q}$-codeletion, large sizes and mutation in isocitrate dehydrogenase. In some studies, with using 50-54 Gy RT dose with 1.8 Gy per fraction, the overall survival rates were similar between the patients whom received radiotherapy in early phase or during progression phase of the disease [1-5].

The difference was about seizures controlling which was better in early phase radiotherapy. Fractionated stereotactic radiotherapy, proton radiotherapy and hyperfractionated radiotherapy may be used to increase the treatment effects however there should be more studies and trials to be done to show their effectiveness in comparison with conventional radiotherapy. In chemotherapy for patients with LGG, patients with Isocitrate DeHydrogenase (IDH)-1 mutations, oligoastrocytoma and oligodendroglioma benefit more from treatment [6-9]. This is really not clear whether PCV can be equally effective as Temozolomide and there should be more studies and trials to be done in this field.

\section{References}

1. Jakola AS, Myrmel KS, Kloster R, Torp SH, Lindal S, et al. (2012) Comparison of a strategy favoring early surgical resection vs a strategy favoring watchful waiting in low-grade gliomas. JAMA 308(18): 18811888.
2. Wijnenga MMJ, French PJ, Dubbink HJ, Dinjens WNM, Atmodimedjo PN, et.al (2018) The impact of surgery in molecularly defined low-grade glioma: an integrated clinical, radiological, and molecular analysis. Neuro Oncol 20(1): 103-112.

3. Karim AB, Maat B, Hatlevoll R, Menten J, Rutten EH, et al. (1996) A randomized trial on dose-response in radiation therapy of low-grade cerebral glioma: European Organization for Research and Treatment of Cancer (EORTC) Study 22844. Int J Radiat Oncol Biol Phys. 36(3): 549-556.

4. Buckner JC, Shaw EG, Pugh SL, Chakravarti A, Gilbert MR, et.al (2016) Radiation plus Procarbazine, CCNU, and Vincristine in Low-Grade Glioma. N Engl J Med 374(14): 1344-1355.

5. Smith JS, Chang EF, Lamborn KR, Chang SM, Prados MD, et.al (2008) Role of extent of resection in the long-term outcome of low-grade hemispheric gliomas. J Clin Oncol 26(8): 1338.

6. Plathow C, Schulz-Ertner D, Thilman C, Zuna I, Lichy M, et.al (2003) Fractionated stereotactic radiotherapy in low-grade astrocytomas: long-term outcome and prognostic factors. Int J Radiat Oncol Biol Phys 57(4): 996-1003.

7. Van den Bent MJ, Afra D, de Witte O, Ben Hassel M, Schraub S, et.al (2005) EORTC Radiotherapy and Brain Tumor Groups and the UK Medical Research Council. Long-term efficacy of early versus delayed radiotherapy for low-grade astrocytoma and oligodendroglioma in adults: the EORTC 22845randomised trial. Lancet 366(9490): 985990.

8. Jeremic B, Shibamoto Y, Grujicic D, Milicic B, Stojanovic M, et.al (1998) Hyper fractionated radiation therapy for incompletely resected supratentorial low-grade glioma. A phase II study. Radiother Oncol 49(1): 49-54.

9. Shaw E, Arusell R, Scheithauer B, O’Fallon J, O’Neill B, et.al (2002) Prospective randomized trial of low- versus high-dose radiation therapy in adults with supratentorial low-grade glioma: $\backslash$ initial report of a north central cancer treatment group/radiation therapy oncology group/eastern cooperative oncology group study. J Clin Oncol 20(9): 2267-2276. 


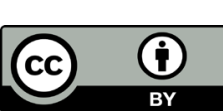

This work is licensed under Creative Commons Attribution 4.0 License

DOI: 10.19080/CTOIJ.2019.14.555889

\section{Your next submission with Juniper Publishers will reach you the below assets}

- Quality Editorial service

- Swift Peer Review

- Reprints availability

- E-prints Service

- Manuscript Podcast for convenient understanding

- Global attainment for your research

- Manuscript accessibility in different formats ( Pdf, E-pub, Full Text, Audio)

- Unceasing customer service

Track the below URL for one-step submission https://juniperpublishers.com/online-submission.php 